\title{
Undisturbed ground temperature in Melbourne
}

Cite as: AIP Conference Proceedings 2121, 080001 (2019); https://doi.org/10.1063/1.5115928

Published Online: 18 July 2019

Sheikh Khaleduzzaman Shah, Lu Aye, and Behzad Rismanchi

\section{ARTICLES YOU MAY BE INTERESTED IN}

Numerical study of a crossflow heat exchanger to investigate thermal performance using nanofluids

AIP Conference Proceedings 2121, 070020 (2019); https://doi.org/10.1063/1.5115927

Fire and evacuation modelling for a pharmaceutical cleanroom facility

AIP Conference Proceedings 2121, 090001 (2019); https://doi.org/10.1063/1.5115929

Towards an improved pyrolysis system: Integrating solar energy based pre-heating system

AIP Conference Proceedings 2121, 090003 (2019); https://doi.org/10.1063/1.5115931

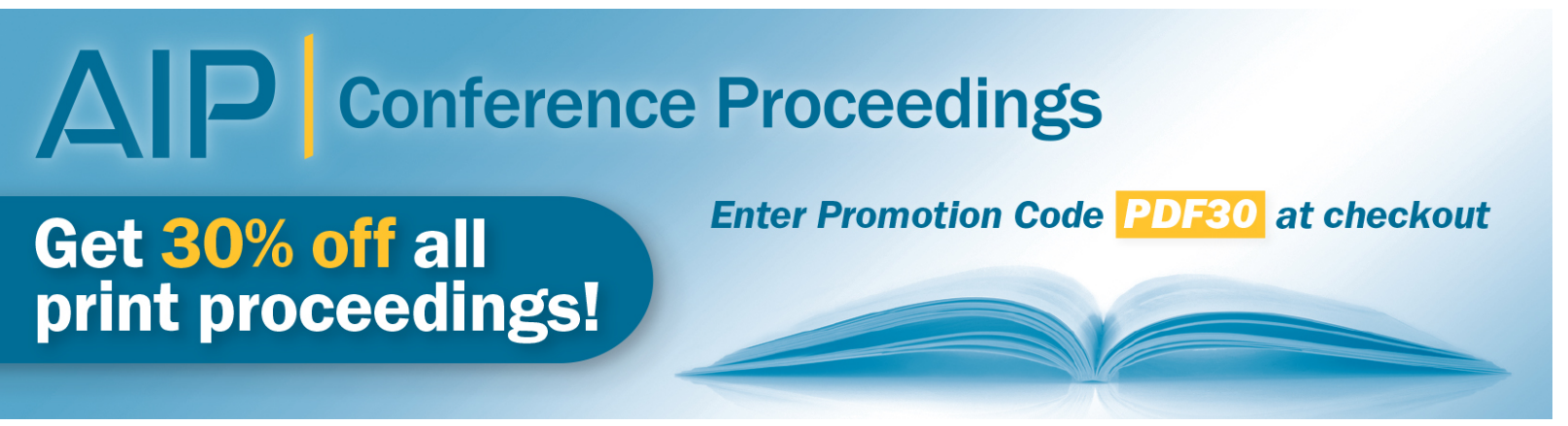




\title{
Undisturbed Ground Temperature in Melbourne
}

\author{
Sheikh Khaleduzzaman Shah ${ }^{\text {a) }}$, Lu Aye ${ }^{\text {b) }}$ and Behzad Rismanchi ${ }^{\text {c) }}$ \\ Renewable Energy and Energy Efficiency Group, Department of Infrastructure Engineering, Melbourne School \\ of Engineering, The University of Melbourne, Victoria 3010, Australia \\ ${ }^{a)}$ sheikhs1@student.unimelb.edu.au

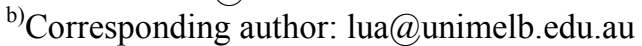 \\ c)brismanchi@unimelb.edu.au
}

\begin{abstract}
The ground surface temperature changes with the diurnal cycle of solar radiation and ambient air temperature. However, the amplitude of the ground temperature variation diminishes with the increase of the depth of the ground and after a certain depth of the ground, it becomes almost constant, where is termed "undisturbed ground temperature (UGT)". At this depth, the seasonal changes of solar radiation and ambient air temperature changes will no longer affect onground temperature. It is one of the important parameters for designing of the ground heat exchangersand building energy analyses. In this study ground temperatures at various depths in Melbourne were investigated using a $40 \mathrm{~m}$ deep borehole instrumented with thermistors. The ground temperatures at various depths $(0 \mathrm{~m}$ to $40 \mathrm{~m})$ in Melbourne were also simulated by using three methods: Kasuda formula method, simulation (TRNSYS, Type 77), and simplified correlation (developed by Ouzzane et al. in 2015) and the results were compared with the measured data. Root mean square error (RMSE) and mean bias error (MBE)were used to validate and verify the methods. It was found that the estimated ground temperatures at 2,21 , and $40 \mathrm{~m}$ depths by Kasuda formula method and simulation (TRNSYS)have the same trends as that of the measured data. The measured annual temperatures of ground at $2 \mathrm{~m}$ depth were between $14.7^{\circ} \mathrm{C}$ and $19.8{ }^{\circ} \mathrm{C}$, while the temperature at $21 \mathrm{~m}$ and $40 \mathrm{~m}$ depths remained almost constant. RMSE and MBEof the simulation (TRNSYS, Type 77) were found to be $1.39^{\circ} \mathrm{C}$, and $-1.39^{\circ} \mathrm{C}$ respectively compared to measured data at $21 \mathrm{~m}$ depth. Based on these values, we conclude that simulation (TRNSYS, Type 77) can reliably predict the ground temperature for the selected sitein Melbourne.
\end{abstract}

Keywords:Undisturbed ground temperature, Borehole, Simulation model, Validation, Melbourne

\section{INTRODUCTION}

The information of ground temperature is required for several purposes such as the design of ground heat exchangers of ground coupled heat pump (GCHP) systems and building energy analysis. At the surface layer, the ground temperature is affected by the solar radiation, ambient air temperature and sky temperature. They influence the rate of heat exchange between the atmosphere and the ground [1]. However, the ground temperature varies at the surface zone (up to $1 \mathrm{~m}$ from the surface). Further, the temperature variation of a ground decrease in lower depths of ground "shallow zone" (depth of $1 \mathrm{~m}$ to $8 \mathrm{~m}$ from the surface). At the deeper zone the ground temperature is almost constant which is called "undisturbed ground temperature (UGT)" [2]. According toKurevija, Vulin [3] UGT is found at a certain depth where seasonal variations in solar radiation and air temperature has no effect.

For a GCHP system,the accurate design of the ground heat exchanger (GHE) is important to avoid the excessive drilling cost or low energy efficiency. Therefore, UGT is one of the most important parameters for sizing GHEs for GCHP or seasonal thermal energy storage (STES) system. Thus, it is essential to accurately determine the UGT of a site, which could be measured directly. To avoid the costly measurements, theoretical modeland/or simulation model may be used to determine the UGT based on long-term weather data and thermal properties of the ground. Kusuda and Achenbach [4] developed ananalytical model which is widely used fordetermining the ground temperature. This model has been implemented in several commercial software tools such as TRNSYS [5]. Recently Ouzzane, Eslami-Nejad [2]proposed a simplified correlation to determine UGT, which uses the ambient air temperatures as inputs. Further, Xing and Spitler [6] presented a validated twoharmonic analytical model for UGT based on data of 19 geographically and climatically diverse measurement sites. They found the average of root mean square errors (RMSEs) of the model for all sites were between $1.4{ }^{\circ} \mathrm{C}$

8th BSME International Conference on Thermal Engineering

AIP Conf. Proc. 2121, 080001-1-080001-6; https://doi.org/10.1063/1.5115928

Published by AIP Publishing. 978-0-7354-1861-5/\$30.00 
and $2.4{ }^{\circ} \mathrm{C}$ at $5,20,50$, and $100 \mathrm{~cm}$ depths. In addition, they have generated a worldwide dataset for UGT by using a model [7]. However, they validated the UGT model forthe surface zone (up to $1 \mathrm{~m}$ ) only.

The analytical formula by Kasuda [4], simulation (TRNSYS, Type 77) [5] and the simplified correlation by Ouzzane et al. [2] may be applied to determine the UGT. The main objective of this investigation is to measure the ground temperatures at various depths on a site in Melbourne then compare with the results from Kasuda formula method, simulation (TRNSYS), and the simplified correlation by Ouzzane et al. (2015)[2]. Three statistical parameters: RMSE,mean bias error (MBE), and Correlation Coefficient (CC)were used for the validation purpose.

\section{METHOD}

The value of UGT is required in designing for various applications such as GCHP. Temperature changes in the soil and ground surface are essential driven by heat fluxes at the ground surface. Various phenomena occurring at the ground surface are presented in Figure $1(\mathrm{a})[2,8,9]$. The surface temperature $\left(T_{S},{ }^{\circ} \mathrm{C}\right)$ is raised by absorbing heat from the solar radiation $\left(S, \mathrm{Wm}^{-2}\right)$. When $S$ reaches the surface of the ground, a part of this flux is absorbed by the ground $(S \beta)$ where $\beta$ is absorption coefficient $(-)$, and the other part is reflected from the surface of the ground. The convective heat $\left(H_{c o n v}, \mathrm{Wm}^{-2}\right)$ exchange occurs between the ground surface and ambient air at temperature $T_{a m b},\left({ }^{\circ} \mathrm{C}\right)$. Besides, the surface losses heat by long-wave radiation $\left(\varepsilon \cdot L W, \mathrm{Wm}^{-2}\right)$ due to sky temperature $\left(T_{s k y},{ }^{\circ} \mathrm{C}\right)$ where $\varepsilon$ is the emittance of ground surface (-). In addition, the surface also losses heat by evaporation $\left(E V, \mathrm{Wm}^{-2}\right)$ of water. The resultant heat flux $\left(q_{c o n d}, \mathrm{Wm}^{-2}\right)$ is transferred into the deeper layer of the ground by conduction.

In this investigation, ground temperatures at various depths $(2 \mathrm{~m}, 21 \mathrm{~m}$ and $40 \mathrm{~m})$ were measured and compared with the results from Kasuda formula method, simulation (TRNSYS), and simplified correlation [2]. The locations of the measurements via the borehole at Burnley campus, The University of Melbourne are shown in Figure 1(b). Three thermistorswere installed at the depths mentioned to measure the temperatures. A data logger was used to record and store the data every 20 min interval throughout the measuring period $\left(12^{\text {th }}\right.$ April 2017 to $14^{\text {th }}$ March 2018). The analytical model, Eq. (1), developed by Kasuda [4] was used to determine the ground temperatures.

$$
T_{G N D\left(D, t_{\text {year }}\right)}=T_{a m b}-\left(T_{\text {amp }} \exp \left(-D \sqrt{\frac{\pi}{365 \alpha}}\right) \times \cos \left(\frac{2 \pi}{365}\left(t_{\text {year }}-t_{\text {shift }}-\frac{D}{2} \sqrt{\frac{365}{\pi \alpha}}\right)\right)\right)
$$

where $T_{G N D\left(D, t_{\text {year }}\right)}$ is the ground temperature $\left({ }^{\circ} \mathrm{C}\right)$ at depth $D(\mathrm{~m})$ below the surface $(0 \mathrm{~m})$ and time of

yeart $t_{\text {year }}$ (day). $T_{a m b}$ is the annual average ambient air temperature $\left({ }^{\circ} \mathrm{C}\right)$ and $T_{a m p}$ is the amplitude of daily average ambient air temperature $\left({ }^{\circ} \mathrm{C}\right)$ annual change. $\alpha\left(\mathrm{m}^{2} \mathrm{day}^{-1}\right)$ is the thermal diffusivity. $t_{\text {shift }}$ refers to the day of the year where the minimum daily average ambient air temperatureis found.

The monthly average ambient air temperatures between Jun 2013 and May 2018 recored[10] atthe nearest Bureau of Meteorology Melbourne Olympic Park station (ID: 086338) were applied and this station was2.6 km away from the study site.The TRNSYS project file used to simulate the ground temperature at various depths is presented in Figure 1(c). Thermophysical properties of ground were estimated based on the average moisture content $(16.3 \% \mathrm{db})$ of the soil samples collected by Lhendup (2013) [11] during drilling of the boreholes. The thermophysical properties of clay and water were taken from[12]. The rule of mixtures was applied to estimate the thermal conductivity, density, specific heat of the wet soil (clay and water). From these estimates, the thermal diffusivity of the ground was calculated.The thermophysical properties of the ground at the site and climate information are shown in Table 1.

TABLE 1. Climate data and thermophysical properties

\begin{tabular}{lcrc}
\hline \multicolumn{1}{c}{ Parameter } & Unit & Value & Reference \\
\hline Annual average ambient air temperature (June 2013 - May 2018) & ${ }^{\circ} \mathrm{C}$ & 16.25 & {$[10]$} \\
The amplitudeof daily average ambient air temperature annual change & ${ }^{\circ} \mathrm{C}$ & 5.25 & {$[10]$} \\
Time shift (monthly average minimum temperature occurrence) & day & 212 & {$[10]$} \\
Thermal conductivity of the ground & $\mathrm{W} \mathrm{m}^{-1} \mathrm{~K}^{-1}$ & 1.18 & Estimated \\
Density of the ground & $\mathrm{kg} \mathrm{m}^{-3}$ & 1387 & Estimated \\
Specific heat of the ground & $\mathrm{J} \mathrm{kg} \mathrm{K}^{-1}$ & 1344 & Estimated \\
Thermal diffusivity of the ground & $\mathrm{m} \mathrm{m}^{2}$ day $^{-1}$ & 0.0547 & Estimated \\
\hline
\end{tabular}




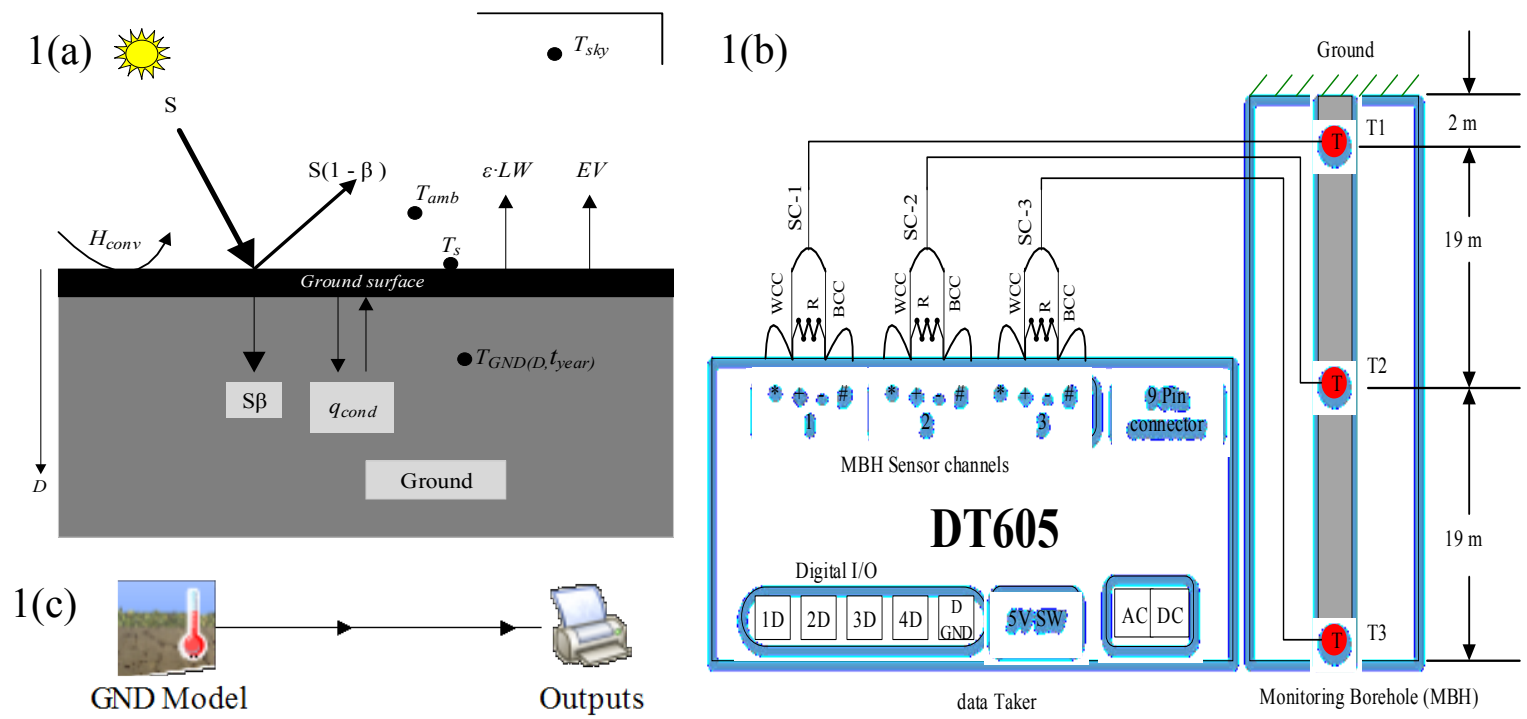

FIGURE 1. (a) Heat fluxes at the surface on the ground, (b) Schematic diagram of the ground temperature measurement system, (c) TRNSYS studio of ground (GND) temperature.

The simplified correlation, Eq. (2) developed by Ouzzane et al. [2]was used to determine the UGT based on the annual average ambient air temperature.

$$
T_{G N D}=\left(17.898+\left(0.951 \times\left(T_{a m b}+273.15\right)\right)\right)-273.15
$$

where $T_{a m b}$ is the annual average ambient air temperature $\left({ }^{\circ} \mathrm{C}\right)$. Eq. $(3-5)$ [13]were used for estimating the statistical parameters (RMSE,BME, CC).

$$
\begin{gathered}
R M S E=\left[\frac{\sum_{i=1}^{N}\left(Y_{i}-X_{i}\right)^{2}}{N}\right]^{0.5} \\
M B E=\left[\frac{\left.\sum_{i=1}^{N}\left(Y_{i}-X_{i}\right)\right]}{N}\right] \\
C C=\frac{\left[\sum\left(\left(Y_{i}-Y_{\text {mean }}\right)\left(X_{i}-X_{\text {mean }}\right)\right)\right.}{\left(\left(\sum\left(Y_{i}-Y_{\text {mean }}\right)^{2}\right)\left(\sum\left(X_{i}-X_{\text {mean }}\right)^{2}\right)\right)^{0.5}}
\end{gathered}
$$

where $X_{i}$ is the $i$ th measured value, $Y_{i}$ is the $i$ th simulated (or calculated) value, $Y_{\text {mean }}$ is the mean of simulated (or calculated) values, $X_{\text {mean }}$ is the mean of measured values and $N$ is the total number of observations. Since the moisture content of the underground soil can have great effects on thermophysical properties, the sensitivity or effects of thermal diffusivity of the ground wereinvestigatedfor Kasuda formula method at $2 \mathrm{~m}$ depth.

\section{RESULTS AND DISCUSSION}

The ground temperatures at theminimum and maximum daily average ambient air occurrence dates are presented in Table 2. The ground surface temperature was varied from summer to winter period due to the changes of the ambient air temperature as well as solar radiation. As per measured data, the UGT was found to be $17.6^{\circ} \mathrm{C}$ at Burnley site, Melbourne. However, in this experiment, the ground temperature was measured at 2 $\mathrm{m}, 21 \mathrm{~m}$, and $40 \mathrm{~m}$ depths only. Therefore, the location of UGT occurrence may be less than $21 \mathrm{~m}$ depth, the 
exact depth could not be identified because we do not have measurements for the depths between $2 \mathrm{~m}$ and $21 \mathrm{~m}$. Hence, further analysis was performed by using TRNSYS (Type 77)simple ground temperature model.

TABLE 2. Measured temperatures $\left({ }^{\circ} \mathrm{C}\right)$ at minimum and maximum daily average ambient air temperatures occurrence dates

\begin{tabular}{lrr}
\hline Location $\backslash$ Date & \multicolumn{1}{c}{$1^{\text {st }}$ July 2017 } & \multicolumn{2}{c}{$28^{\text {th }}$ January 2018 } \\
\hline Ambient air & Minimum daily average, 7.48 & Maximum daily average, 32.89 \\
At 2 m depth & 16.78 & 18.84 \\
At 21 m depth & 17.63 & 17.62 \\
At 40 m depth & 17.70 & 17.64 \\
\hline
\end{tabular}

Figure 2 shows the temperature profile of ground at various depths based on measured, Kasuda formula method,and simulation (TRNSYS). The data gaps in the curves are for the duration the measured data are not available $\left(14^{\text {th }}\right.$ March to $12^{\text {th }}$ April). It was found that Kasuda formula method and simulation (TRNSYS) data are the same at $2 \mathrm{~m}, 21 \mathrm{~m}$ and $40 \mathrm{~m}$ depth since TRNSYS (Type 77) used Kasuda formula. Therefore the temperatures for measured, and simulation (TRNSYS) are shown in Figure 2. The simulation (TRNSYS) followed the same pattern of measured data at $2 \mathrm{~m}$ depth. The average UGT was foundto be 17.64 , and $16.25{ }^{\circ} \mathrm{C}$ at $21 \mathrm{~m}$ depth for the measurement, and simulation (TRNSYS) respectively. The average UGT was found at 17.68, and $16.25{ }^{\circ} \mathrm{C}$ at $40 \mathrm{~m}$ depth based on measurement, and simulation (TRNSYS), respectively. The deviation of UGT was found $1.39{ }^{\circ} \mathrm{C}$ at $21 \mathrm{~m}$ depth in between measured, and simulation (TRNSYS) because of ambient air temperature is the most influential parameter to determine the UGT by simulation (TRNSYS) where the value of annual average ambient air temperature was found low. It was found that the measured temperature values have a very minor difference in between $21 \mathrm{~m}$ and $40 \mathrm{~m}$ depth, and they arewithin measurement accuracy of the thermistors. However, the UGT calculated by the simplified correlation [2] was found to be $19.97^{\circ} \mathrm{C}$. The deviation was found to be $2.28^{\circ} \mathrm{C}$.

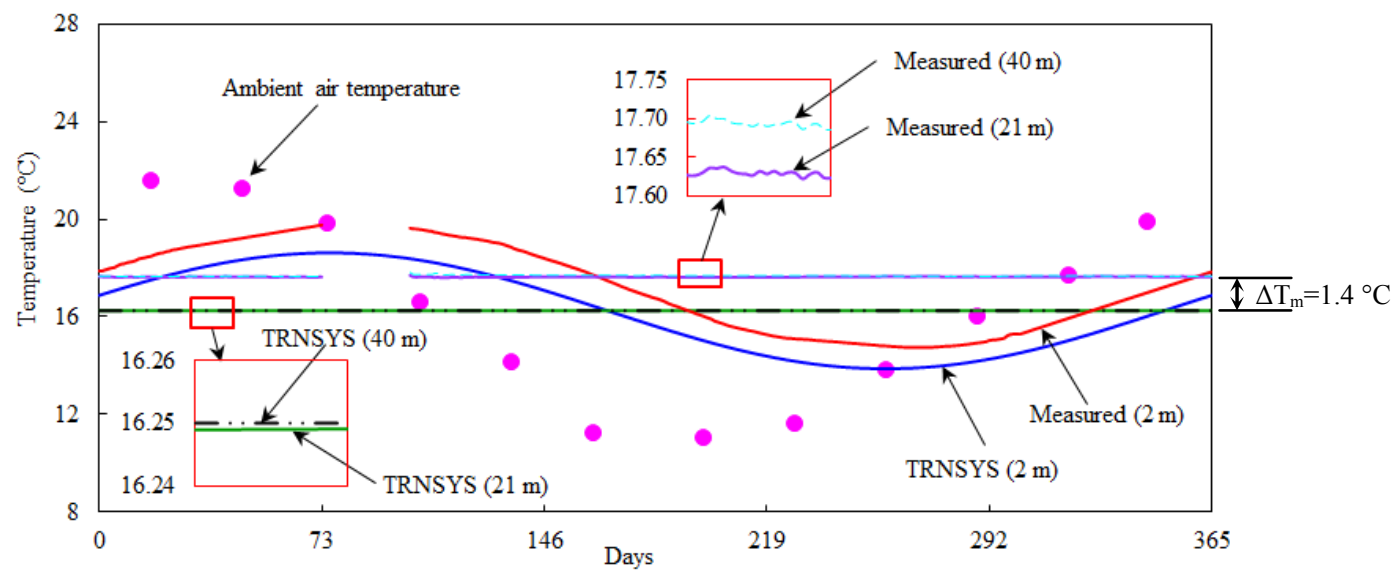

FIGURE 2.Monthly average ambient air temperature and ground temperature profiles (Burnley, Melbourne)

However, for the local site (Burnley, Melbourne) variation in average ground temperature $\left(\Delta \mathrm{T}_{\mathrm{m}},{ }^{\circ} \mathrm{C}\right)$ was found to be $1.4{ }^{\circ} \mathrm{C}$ between TRNSYS and measured at $21 \mathrm{~m}$ and $40 \mathrm{~m}$ depthas shown in Figure 2. As described the various heat fluxes(Figure 1(a)), the ground temperature is highly influenced by the ambient air temperature as per different UGT equation models [2,9] where other heat fluxes were almost cancelled out by each other. In addition, Baggs [14] investigated on remote prediction of ground temperature in Australia soil. The measured UGT was found to be $1.8{ }^{\circ} \mathrm{C}$ higher than the annual average air temperature in New South Wales. The values forRMSEsand MBEs are presented in Table 3. The maximum RMSE was found for simplified correlation and minimum at simulation (TRNSYS) at $2 \mathrm{~m}$ depth.

TABLE 3. Statistical parameters of the models/formula compare to measured values

\begin{tabular}{lcc|rr|rr}
\hline & \multicolumn{2}{c}{$2 \mathrm{~m}$ depth } & \multicolumn{2}{c}{$21 \mathrm{~m}$ depth } & \multicolumn{2}{c}{$40 \mathrm{~m}$ depth } \\
\hline & $\begin{array}{c}\text { TRNSYS } \\
\text { Type } 77\end{array}$ & $\begin{array}{c}\text { Simplified } \\
\text { correlation }\end{array}$ & $\begin{array}{c}\text { TRNSYS } \\
\text { Type 77 }\end{array}$ & $\begin{array}{c}\text { Simplified } \\
\text { correlation }\end{array}$ & $\begin{array}{c}\text { TRNSYS } \\
\text { Type 77 }\end{array}$ & $\begin{array}{c}\text { Simplified } \\
\text { correlation }\end{array}$ \\
\hline RMSE $\left({ }^{\circ} \mathrm{C}\right)$ & 1.03 & 2.89 & 1.39 & 2.33 & 1.43 & 2.28 \\
MBE $\left({ }^{\circ} \mathrm{C}\right)$ & -1.01 & 2.89 & -1.39 & 2.33 & -1.43 & 2.28 \\
\hline
\end{tabular}


As per RMSEs and MBEs at $21 \mathrm{~m}$ and $40 \mathrm{~m}$ depth of the TRNSYS simulations (Figure 3), it could be concluded that there are negligible effects of thermophysical properties of ground on UGT. However, ground temperature was found affected by thermophysical properties at $2 \mathrm{~m}$ depth (Surface zone).Therefore the effects of thermal diffusivity of ground at $2 \mathrm{~m}$ depth on statistical parameters were investigated (see Figure3). It was found that there is a thermal diffusivity value which provides the minimum RMSEor the maximum CC. The minimum RMSE was found $1.03{ }^{\circ} \mathrm{C}$ where maximum $\mathrm{CC}$ was found 0.99 at 0.045 and $0.055 \mathrm{~m}^{2}$ day $^{-1}$ thermal diffusivity. However, MBE was found decreased with the increaseof thermal diffusivity of the ground. The MBE was found to be -1.00 and $-1.01{ }^{\circ} \mathrm{C}$ for 0.045 and $0.055 \mathrm{~m}^{2}$ day ${ }^{-1}$ thermal diffusivity respectively.

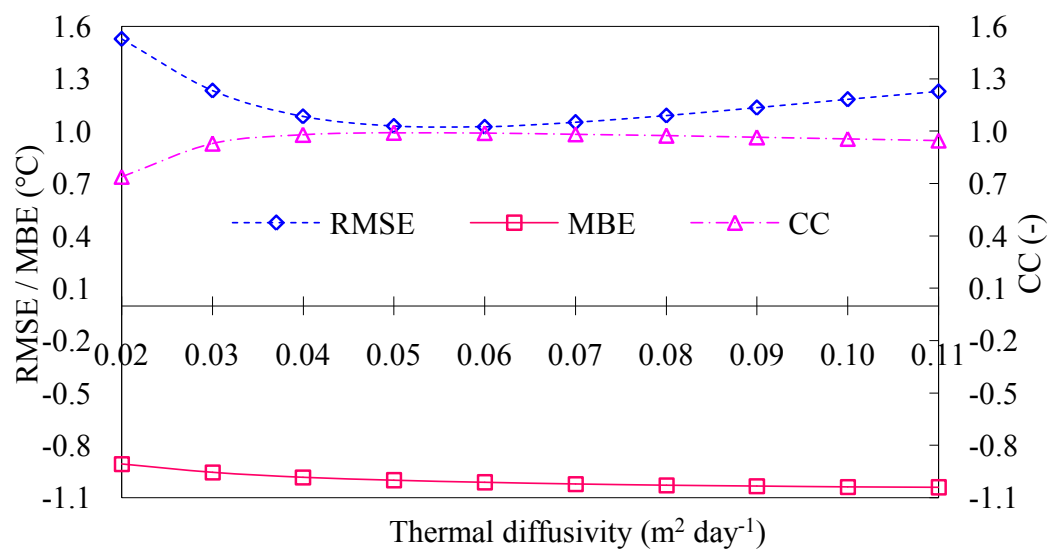

FIGURE3. Effect of thermal diffusivity of ground on the ground temperature at $2 \mathrm{~m}$ depth.

Figure 4 shows the monthly ground temperature variations with various depths. Simulation (TRNSYS) was used to determine the ground temperature at $0,3,6,9,10,11,12,13,14,15,18,21$, and $40 \mathrm{~m}$ depthon the representative dates [15] of every month (from January to December). At $0 \mathrm{~m}$ depth, the maximum ground surface temperature was foundto be $21.38{ }^{\circ} \mathrm{C}$ inJanuary and the minimumground surface temperature was foundto be $11.15^{\circ} \mathrm{C}$ inJuly. However, it was found that the UGT is $16.25^{\circ} \mathrm{C}$ which begins from $12 \mathrm{~m}$ depth of the ground where the maximum variation of UGT is $0.09^{\circ} \mathrm{C}$ in between summer and winter period at $12 \mathrm{~m}$ depth.However, the measured UGT was found to be $17.6^{\circ} \mathrm{C}$ which is higher thanthe simulated value $\left(16.25^{\circ} \mathrm{C}\right)$. It should be noted thatType 77 or Kasuda formula considersambient air temperatureonly, not the effect of ground heat flux. The measured UGT at $40 \mathrm{~m}$ depth is slightly higher than that of $21 \mathrm{~m}$ depth.The value of UGT at $21 \mathrm{~m}$ is higher than the annual average ambient air temperature. The variations of temperatures at specific depthsare presented in Table 4.

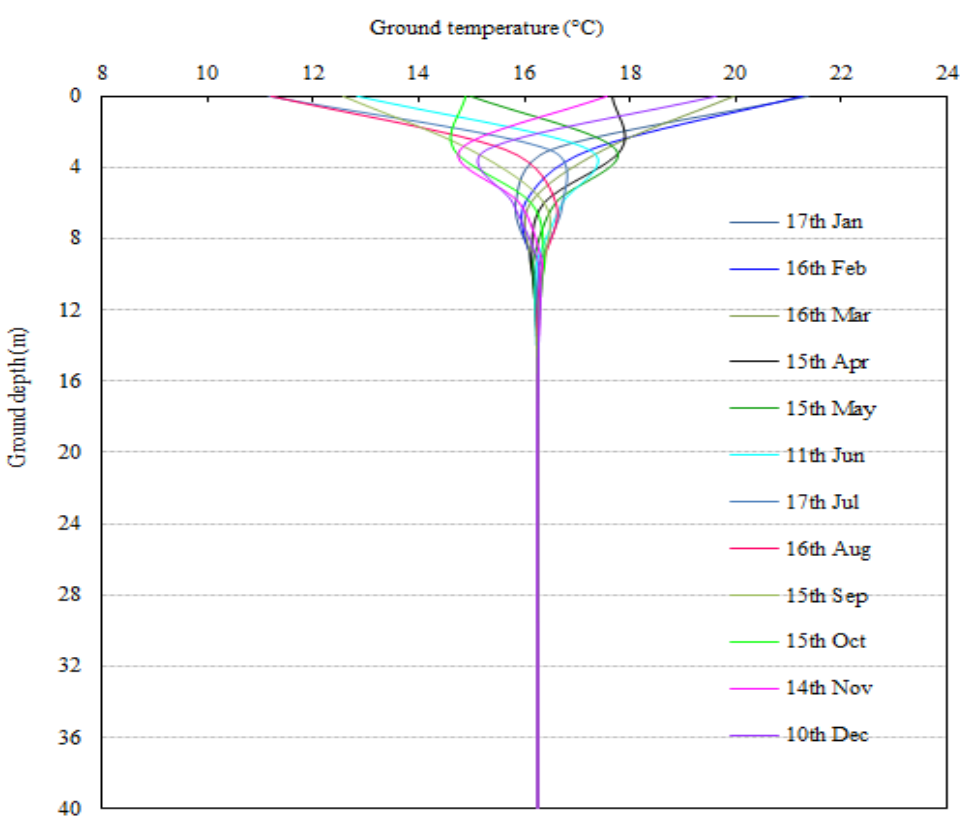

FIGURE4.Monthlyground temperature Vs ground depth at Melbourne. 
TABLE 4. UGT variation at specific depths

\begin{tabular}{cccccccccccccc}
\hline Depth $(\mathrm{m})$ & 0 & 3 & 6 & 9 & 10 & 11 & 12 & 13 & 14 & 15 & 18 & 21 & 40 \\
Temp.variation $\left({ }^{\circ} \mathrm{C}\right)$ & 10.23 & 3.17 & 0.94 & 0.29 & 0.19 & 0.13 & 0.09 & 0.06 & 0.04 & 0.03 & 0.01 & 0.0 & 0.0 \\
\hline
\end{tabular}

\section{CONCLUSIONS}

The UGT on site in Melbourne was analysed based on measured, Kasuda formula method,simulation (TRNSYS), and simplified correlation[2]. The average UGT was measured to be $17.64^{\circ} \mathrm{C}$ and estimated to be $16.25{ }^{\circ} \mathrm{C}$ at $21 \mathrm{~m}$ depth by TRNSYS, Type 77 . However, the UGT was estimated to be $19.97{ }^{\circ} \mathrm{C}$ by the simplified correlation[2]. To compare the data,statistical parameters such as RMSE, and BME were used to validate TRNSYS Type 77. Further, it was found that thethermophysical properties have no effect on the UGT. However thermal diffusivity has an effect on ground temperature at $2 \mathrm{~m}$ depth. As per simulated results it was found that the UGT begins from the depth of $12 \mathrm{~m}$ in Melbourne.

\section{ACKNOWLEDGEMENTS}

Sheikh Khaleduzzaman Shah would like to thank The University of Melbourne, Australia for providing a Melbourne Research Scholarship Award.

\section{REFERENCES}

1. G.A. Florides and S.A. Kalogirou, Annual ground temperature measurements at various depths. 2005, Higher Technical Institute: Nicosia 2152, Cyprus.

2. M. Ouzzane, P. Eslami-Nejad, M. Badache and Z. Aidoun, New correlations for the prediction of the undisturbed ground temperature. Geothermics, 2015. 53: pp. 379-384.

3. T. Kurevija, D. Vulin and V. Krapec. Influence of Undisturbed Ground Temperature and Geothermal Gradient on the Sizing of Borehole Heat Exchangers. in World Renewable Energy Congress 2011. 8-11 May 2011. Linköping, Sweden.

4. T. Kusuda and P.R. Achenbach, Earth temperature and thermal diffusivity at selected stations in the United States. ASHRAE Transactions, 1965. 71 (Part 1).

5. S. Klein, W. Beckman, J. Mitchell, J. Duffie, N. Duffie, T. Freeman, et al., TRNSYS 16-A TRaNsient system simulation program, user manual. 2004, Solar Energy Laboratory. Madison: University of Wisconsin-Madison.

6. L. Xing and J.D. Spitler, Prediction of undisturbed ground temperature using analytical and numerical modeling. Part I: Model development and experimental validation. Science and Technology for the Built Environment, 2017. 23 (5): pp. 787-808.

7. L. Xing and J.D. Spitler, Prediction of undisturbed ground temperature using analytical and numerical modeling. Part II: Methodology for developing a world-wide dataset. Science and Technology for the Built Environment, 2017. 23 (5): pp. 809-825.

8. M. Badache, P. Eslami-Nejad, M. Ouzzane, Z. Aidoun and L. Lamarche, A new modeling approach for improved ground temperature profile determination. Renewable Energy, 2016. 85: pp. 436-444.

9. M. Gwadera, B. Larwa and K. Kupiec, Undisturbed Ground Temperature-Different Methods of Determination. Sustainability, 2017.9 (11): pp. 2055.

10. Bureau of Meteorology. Climate statistics for Australian locations. 2018 [cited 201813 september ]; Available from: http://www.bom.gov.au.

11. T. Lhendup, "Development of an inter-seasonal thermal storage system", Ph.D. thesis, in Infrastructure Engineering. 2013, The University of Melbourne, Australia.

12. Y. Dong, J.S. McCartney and N. Lu, Critical Review of Thermal Conductivity Models for Unsaturated Soils. Geotechnical and Geological Engineering, 2015. 33 (2): pp. 207-221.

13. M. Iqbal, "Appendix D - Methods of Statistical Tests", in An Introduction to Solar Radiation, edited by M. Iqbal. Academic Press, 1983, pp. 383-6.

14. S.A. Baggs, Remote prediction of ground temperature in Australian soils and mapping its distribution. Solar Energy, 1983. 30 (4): pp. 351-366.

15. J.A. Duffie and W.A. Beckman, "Solar Engineering of Thermal Processes”, John Wiley \& Sons, Inc. 2013, pp. 621-634. 